\title{
P02.120. Qualitative systemic review on Complementary and Alternative Medicine treatments in Inflammatory Bowel Diseases
}

\author{
J Langhorst", R Lauche, H Vorpeil, M Baecker, P Klose, G Dobos \\ From International Research Congress on Integrative Medicine and Health 2012 \\ Portland, Oregon, USA. 15-18 May 2012
}

\section{Purpose}

We performed a systematic review (with qualitative metaanalysis) for Complementary and Alternative Medicine (CAM) as defined by the National Institute of Health, with the exception of dietary and nutritional supplements, in Inflammatory Bowel Disease (IBD), i.e., Crohn's disease (CD) and ulcerative colitis (UC).

\section{Methods}

A computerized search of databases (Cochrane Library, Medline, PsychINFO, and Scopus) through June 2011 was performed. We screened the reference sections of original studies and systematic reviews in the English language for CAM in IBD, CD and UC. Randomized controlled trials (RCT) and controlled trials (CT) were included. RCTs comparing treatment to controls were assessed by a methodological quality score.

\section{Results}

A total of 11 RCTs and 4 CTs in herbal therapy (i.e., plantago ovata, boswellia, barley foodstuff, curcumin, tormentil, aloe-vera gel, wheatgrass-juice, evening primrose oil, andrographis paniculata, sophora and wormwood), $1 \mathrm{RCT}$ in trichuris suis ovata, 2 RCTs in mind-body interventions and self-management, 2 RCTs in acupuncture, and 1 RCT in balneotherapy were found. The 17 RCTs had an average study size of 61 patients (range 20 - 126) with a number of groups ranging from two to three. The quality score assessment of the RCTs yielded a mean score of 57 out of 100 .

University of Duisburg, Complementary and Integrative Medicine, Essen, Germany
Cite this article as: Langhorst et al.: P02.120. Qualitative systemic review on Complementary and Alternative Medicine treatments in Inflammatory Bowel Diseases. BMC Complementary and Alternative Medicine 2012 12(Suppl 1):P176.
Submit your next manuscript to BioMed Central and take full advantage of:

- Convenient online submission

- Thorough peer review

- No space constraints or color figure charges

- Immediate publication on acceptance

- Inclusion in PubMed, CAS, Scopus and Google Scholar

- Research which is freely available for redistribution 